\title{
Major Challenges and Prospects of Food Security System in India
}

\author{
Dr. Nawaz Ahmed and Taseem Ahmed
}

\begin{abstract}
The word "Food Security" is related with the political development between two super-powers in year 1973. It was realized that food can be used as a biggest weapon to have an upper hand in world politics. In an emergent meeting of FAO at Rome the origin of the word food security came into existence. At this critical juncture FAO defined food security as no one should go hungry to the bed irrespective of the male or female and children and finally it is the duty of the humanity also to solve the problem. Later on in the year 2001 Food Security was being defined by various scholars of the World and they related it not only with basic food items but with non-basic food items (luxurious and protective food items) which created the situation of confusion with the basic definition and lastly it is observed that there is no difference between food security and food self sufficiency as well as with basic food items and non-basic food items. All the protective food items as nutritive food items are now being included in the meaning and concept of food security. The Word Food Security is defined as to ensure that all people at all times have both physical and economic access to the basic food they need.
\end{abstract}

Key Words: Food Security, biggest weapon, humanity, self sufficiency

\section{Introduction}

Food security refers to the availability of food and one's access to it. A household is considered foodsecure when its occupants do not live in hunger or fear of starvation. The World Health Organization defines three facets of food security: food availability, food access, and food use. Food availability is having available sufficient quantities of food on a consistent basis. Food access is having sufficient resources, both economic and physical, to obtain appropriate foods for a nutritious diet. Food use is the appropriate use based on knowledge of basic nutrition and care, as well as adequate water and sanitation. The FAO adds a fourth facet: the stability of the first three dimensions of food security over time. The origin of the word "Food Security" is related with the political development between two super-powers in year 1973. It was realized that food can be used as a biggest weapon to have an upper hand in world politics. A very critical food deficit situation was created due to entry of USSR in the international food market in a big manner which de-exhausted a major stock and when all the importer countries reached to American food market, America showed its inability to supply the food grain to these countries. Since then all the imported countries lost faith in America.

In a meeting of FAO at Rome, the origin of the word food security came into existence. At this critical juncture FAO defined food security as no one should go hungry to the bed irrespective of the male or female and children and finally it is the duty of the humanity also to solve the problem. Later on in the year 2001 Food Security was being defined by various scholars of the World and they related it not only with basic food items but with non-basic food items (luxurious and protective food items) which created the situation of confusion with the basic definition and lastly it is observed that there is no difference between food security and food self sufficiency as well as with basic food items and non- basic food items. All the protective food items as nutritive food items are now being included in the meaning and concept of food security. The Word Food Security is defined as to ensure that all people at all times have both physical and economic access to the basic food they need.As for as the Food security system in India is concerned, it is related to the distribution of food-grain in the food deficit areas, towns and villages either through Govt. agencies or through non Govt. agencies. But it is a helpless situation when there is a drought, earthquake, floods, disaster, transportation problems and riots etc and the Govt. is either able to handle this situation or not. Fluctuation in Food grain production in India is still a major threat to food security due to micro-climatic change which creates a situation of sudden low and high production. There are large numbers of components related to the food security system in India which are known or even unknown.

In India FCI stocking system is related to cater the need of this situation but it is such a costly economic affair that no Govt. can solve the problem in such a natural disasters cited above. Many of us have doubted the existence of FCI as political, i.e., its came into existence only to help the big farmers. However, food security in India should be treated in relation to the small and marginal farmers and the population below the poverty line which are not able to purchase enough food-grain. It is going to emerge as a big food problem which can be included in the definition of the food security.

There are various components threatening the food security strategies to tackle this critical issue. 


\section{SPECIFIC AIMS OF FOOD SECURITY}

Food Security has three specific aims:-

- To ensure the production of adequate food supplies.

- To maximize the stability in the flow of supplies.

- To secure access to available supplies on the part of these who need them.

\section{MAJOR PROBLEMS IN INDIA}

It has been found that India at present finds itself in the midst of a paradoxical situation: endemic masshunger coexisting with the mounting foodgrain stocks. The foodgrain stocks available with the Food Corporation of India (FCI) stand at an all time high of 62 million tonnes against an annual requirement of around 20 million tonnes for ensuring food security. Still, an estimated 200 million people are underfed and 50 million on the brink of starvation, resulting in starvation deaths. The paradox lies in the inherent flaws in the existing policy and implementation bottlenecks. 50 crore population along with stock of $300 \mathrm{mmt}$ while need is only $100 \mathrm{mmt}$ for 50 crore population starving in the world while distribution is not proper.

- Access of food is important

- Equitable food distribution would have avoided Bengal Famine in 1943 ( Sen 1981)

\section{MAJOR CHALLENGES}

India's food security policy has a laudable objective to ensure availability of foodgrains to the common people at an affordable price and it has enabled the poor to have access to food where none existed. The policy has focused essentially on growth in agriculture production (once India used to import foodgrains) and on support price for procurement and maintenance of rice and wheat stocks. The responsibility for procuring and stocking of foodgrains lies with the FCI and for distribution with the public distribution system (PDS).

Minimum support price: The FCI procures foodgrains from the farmers at the government announced minimum support price (MSP). The MSP should ideally be at a level where the procurement by FCI and the offtake from it are balanced. However, under continuous pressure from the powerful farmers lobby, the government has been raising the MSP and it has now become higher than what the market offers to the farmers. Also, with quality norms in the procured grains not strictly observed, farmers pressurize the FCI to procure grains beyond its procurement target and carrying capacity. The MSP has now become more of a procurement price rather than being a support price to ensure minimum production. The rich farmers and traders have cornered most of the benefits under the support price policy. The small farmers lack access to FCI and being steeped in poverty resort to distress selling. Constricted warehousing facility has further aggravated their miseries. At times, the same farmers later pay more to buy it from PDS.

Input subsidies: Over the years, to keep foodgrain prices at affordable levels for the poor, the government has been imposing restrictions on free trade in foodgrains. This has suppressed foodgrain prices in the local market, where the farmers sell a part of their produce and as compensation; they are provided subsidies on agriculture inputs such as fertilizers, power and water. These subsidies have now reached unsustainable levels and also led to large scale inefficiencies in the use of these scarce inputs. Overuse of fertilizer and water has led to waterlogging, salinity, depletion of vital micronutrients in the soil, and reduced fertility. The high subsidies have come at the expense of public investments in the critical agriculture infrastructure, thereby reducing agriculture productivity. Besides the high MSP, input subsidies and committed FCI purchases have distorted the cropping pattern with wheat and paddy crops being grown more for the MSP they fetch, despite there being relatively less demand for them. Punjab and Haryana are classic examples here. This has also led to a serious imbalance in inter-crop parities despite no significant increase in the yield of wheat and paddy.

Issue price: The people are divided into two categories: below poverty line (BPL) and above poverty line (APL), with the issue price being different for each category. However, this categorization is imperfect and a number of deserving poor have been excluded from the BPL fold. Moreover, some of the so called APL slip back to BPL say with failure of even one crop and it is administratively difficult to accommodate such shifts.

To reduce the fiscal deficit, the government has sought to curtail the food subsidy bill by raising the issue price of foodgrains and linking it to the economic cost at which the FCI supplies foodgrains to the PDS. The economic cost comprises the cost of procurement, that is, MSP, storage, transportation and administration and is high mainly because of the artificially inflated MSP and also due to the operational inefficiencies of the FCI. This has pushed the issue price to APL category higher than the market rates and to BPL category beyond their purchasing power, resulting in plummeting of offtake from the PDS. (Table 1)

No doubt this table is reliable but Ziegler in his national health survey report has mentioned on the basis of the health survey that especially the children are suffering from malnutrition and under nutrition which 
is 74 per cent in 2001 and 78 per cent in 2005 . How far this table is reliable is a matter of great concern especially for food security?

Table 1:- Percent below poverty line All India (Based on Food Grains)

\begin{tabular}{|c|c|}
\hline Year & Below poverty line (\%) \\
\hline $1973-74$ & 54.88 \\
\hline $1977-78$ & 51.32 \\
\hline $1983-84$ & 44.48 \\
\hline $1987-88$ & 38.86 \\
\hline $1993-94$ & 35.97 \\
\hline $1999-2000$ & 26.10 \\
\hline $2007-08$ & 19.3 \\
\hline $2009-10$ & 30.0 \\
\hline
\end{tabular}

Source: - Planning Commission 2009-10

Also, the low quality of PDS grains and the poor service at PDS shops have forced many people to switchover to market, which offers better quality grains, allows purchase on credit and ensures flexibility to purchase in small quantities. Also, the high-priced, low-quality Indian rice and wheat find little place in the international market. Recently, two Indian consignments were rejected even by Iraq on quality considerations. The result is bulging stocks with FCI amidst widespread starvation.

Market demand: The PDS entitlement meets only around 25 per cent of the total foodgrain requirement of a BPL family and it has to depend more on the market for meeting its needs. Also with the APL families essentially opting for market purchases, the market demand has risen. However, the massive FCI procurement has crowded out the market supplies, resulting in a relative rise in rates. The poor are the most hurt in this bargain.

Emerging Issue of Small and Marginal Farmers: it has been observed that about 80 per cent of the total operational land holdings belong to small and marginal farmers. Future of this group is going to pose a serious threat to food security because of the low income from agriculture and in the absence of non farm income. Thus future seems to be very dangerous for the nation if the nation is not alert to include this matter in planning the situation, 'a hungry man can never be a peaceful man' and may become a very critical as it is being seen in many parts of India.

Food-for-work scheme: The government is running food-for-work scheme to enhance purchasing power to the poor who get paid for their labour in cash and foodgrains. The scheme is, however, not successful.

\section{MAJOR COMPONENTS OF FOOD SECURITY}

$>$ Fluctuation in Food-grain Production- A major threat to Food Security.

$>$ Accessibility of food is based on the transportation network and income.

$>$ Local Food-grain production- a major supporting factor to food security.

$>$ Poor warning system- a major issue to tackle the problem in a faster manner

$>$ Poor Food stocking locally and regionally -for easy handling of food.

$>$ Climate Change - still a most misunderstood phenomena

$>$ Insensitive attitude towards food distribution

$>$ Natural disasters and Food distribution

$>$ Human caused disasters and Food distribution

$>$ Political awareness about food security. (Table 2 and table 3)

Table 2:- Fluctuation in Food-grain Production in India (Decade 1990-1999 was declared as most favourable for agriculture development)

\begin{tabular}{|c|c|c|}
\hline Year & Production (MMT) & Fluctuation \\
\hline $1991-92$ & 168.4 & +0.0 \\
\hline $1992-93$ & 179.5 & +11.1 \\
\hline $1993-94$ & 184.3 & +4.5 \\
\hline $1994-95$ & 191.5 & +7.2 \\
\hline $1995-96$ & 180.4 & -11.1 \\
\hline
\end{tabular}




\begin{tabular}{|c|c|c|}
\hline $1996-97$ & 199.4 & +19.02 \\
\hline $1997-98$ & 192.4 & -7.01 \\
\hline $1998-99$ & 202.5 & +10.1 \\
\hline $2010-2011$ & 218.2 & +15.7 \\
\hline
\end{tabular}

Source: - Planning Commission 2000, 2011

Table 3:- Availability of Food-grain and pulses

\begin{tabular}{|c|c|c|c|}
\hline Year & Cereals (Production) & $\begin{array}{c}\text { Pulses } \\
\text { (Production) }\end{array}$ & $\begin{array}{c}\text { Foodgrains } \\
\text { (Production) }\end{array}$ \\
\hline 1990 & 431 & 41 & 472 \\
\hline 1991 & 468 & 41 & 510 \\
\hline 1992 & 434 & 34 & 468 \\
\hline 1993 & 427 & 36 & 464 \\
\hline 1994 & 434 & 37 & 471 \\
\hline 1995 & 496 & 38 & 450 \\
\hline 1996 & 452 & 33 & 485 \\
\hline 1997 & 473 & 38 & 512 \\
\hline 1998 & 450 & 33 & 484 \\
\hline 2011 & 420 & 87 & 508 \\
\hline
\end{tabular}

Source: - Planning Commission 2000, 2011

\section{TO ENHANCE FOOD SECURITY}

1. Agricultural Development- integrated approach

2. More food production- balance between food and horticulture.

3. More food reserves

4. The functioning of natural and International food market.

5. Foreign exchange of importing countries.

6. Trade liberalization

7. Purchasing power of poorest strata people

8. Financial resources and technical assistance.

9. Food aid during emergency- drought, floods, earthquake, crop-failure etc.

\section{ACTION PLAN}

1. Equitable use of Environmental system (water use 1940-1980 doubled and 2000 again doubled) water, land, flora, fauna and atmosphere, both developed and developing countries, eroding the production base

2. Sustainable Livelihood Security for the poor ( Degradation of resources, Environmental Refugees)

3. Symphonic Agricultural Systems ( Production - marketing - consumption chain post - harvest technology)

4. Science and technology ( Latest technology with application will minimize poverty and hunger, HYV seeds etc)

5. Knowledge and skilled sharing ( Illiteracy is still widespread in developing countries)

6. Resource Mobilization and usage

7. Political commitment and Accountability

\section{STRATEGY FOR FOOD SECURITY}

1. In general the security can be achieved by adopting the following measures:-

i.Increasing the national production at any cost of production especially on the import of basic food items.

ii.Co - operative system in accelerating food production growth rate, co-operation in exploitation of common resources and transfer of technology, and trade in agricultural inputs.

iii.Transport network should be managed in such a way to tackle the problem.

2. Food supplies security through trade and emergency arrangement, i.e., food sharing scheme, regional food security reserve, international food trade cooperation, food trade financial fund and lastly the 
process of negotiation. Political commitment of food security- A solidarity pact in various types of governments and even in an area of regional hostilities.

3. Cooperatives action in establishing food security infrastructures such as transport, road network, agricultural infrastructure during the drought period.

4. Common stock policies at regional level not only for foodgrains but other items of human survival so that nation can work in an integrated manner to remove the abnormalities.

5. Creating regional food reserves by establishing a common secretariat and common food stocks should be created to combat the problem.

6. Strategy for taster agricultural growth - such type of attempt should be done in countries of high potential and agricultural resource countries so that eco-friendly agriculture can be adopted without misusing the land resources. Early maturing crops should be adopted without misusing the land resources. Early maturing crops should be introduced to produce the items needed by the suffering population in a much faster manner as compared to the crops, which mature in long duration.

7. Neighbouring countries should specialize their agriculture according to their land capability factors and special land should be devoted to special quality production.

\section{MAIN SUGGESTIONS}

There is a need to shift from the existing expensive, inefficient and corruption ridden institutional arrangements to those that will ensure cheap delivery of requisite quality grains in a transparent manner and are self-targeting.

Futures market and free trade: The present system marked by input subsidies and high MSP should be phased out. To avoid wide fluctuations in prices and prevent distress selling by small farmers, futures market can be encouraged. Improved communication systems through the use of information technology may help farmers get a better deal for their produce. Crop insurance schemes can be promoted with government meeting a major part of the insurance premium to protect the farmers against natural calamities.

To start with, all restrictions on foodgrains regarding inter-State movement, stocking, exports and institutional credit and trade financing should be renounced. Free trade will help make-up the difference between production and consumption needs, reduce supply variability, increase efficiency in resource-use and permit production in regions more suited to it.

Food-for-education programme: To achieve cent per cent literacy, the food security need can be productively linked to increased enrolment in schools. With the phasing out of PDS, food coupons may be issued to poor people depending on their entitlement.

Modified food-for-work scheme/ direct subsidies: With rationalization of input subsidies and MSP, the Central Government will be left with sufficient funds, which may be given as grants to each State depending on the number of poor. The State government will in turn distribute the grants to the village bodies, which can decide on the list of essential infrastructure, work the village needs and allow every needy villager to contribute through his labour and get paid in food coupons and cash.

Community grain storage banks: The FCI can be gradually dismantled and procurement decentralized through the creation of foodgrain banks in each block/ village of the district, from which people may get subsidised foodgrains against food coupons. The food coupons can be numbered serially to avoid frauds. The grain storage facilities can be created within two years under the existing rural development schemes and the initial lot of grains can come from the existing FCI stocks. If culturally acceptable, the possibility of relatively cheap coarse grains, like bajara and ragi and nutritional grains like millets and pulses meeting the nutritional needs of the people can also be explored. This will not only enlarge the food basket but also prevent such locally adapted grains from becoming extinct. The community can be authorized to manage the food banks. This decentralized management will improve the delivery of entitlements, reduce handling and transport costs and eliminate corruption, thereby bringing down the issue price substantially. To enforce efficiency in grain banks operation, people can also be given an option to obtain foodgrains against food coupons from the open market, if the rates in the grain banks are higher, quality is poor or services are deficient. A fund can be set up to reimburse the food retailers for the presented coupons. This competition will lead to constant improvement and lower prices. It must also be mandatory to maintain a small buffer stock at the State level, to deal with exigencies.

Agriculture productivity Enhancement: The government, through investments in vital agriculture infrastructure, credit linkages and encouraging the use of latest techniques, motivate each district/ block to achieve local self-sufficiency in foodgrain production. However, instead of concentrating only on rice or wheat, the food crop with a potential in the area must be encouraged. Creation of necessary infrastructure like irrigation 
facilities will also simulate private investments in agriculture. The focus on accelerated foodgrains production on a sustainable basis and free trade in grains would help create massive employment and reduce the incidence of poverty in rural areas. This will lead to faster economic growth and give purchasing power to the people.

A five-year transitory period may be allowed while implementing these. Thus, India can achieve food security in the real sense and in a realistic timeframe.

\section{References}

[1]. Adams, R., and Wu, M. (Eds.). (2002). Pisa 2000 technical report. Paris: Organization for Economic Co-Operation and Development. (http://www.pisa.oecd.org/dataoecd/53/19/33688233.pdf).

[2]. Acharya A. 1992, Food Security System in India Concept Pub Co. New Delhi pp 1-270.

[3]. Adams, E.J., Grummer-Strawn, L., and Chavez, G. (2003). Food security is associated with increased risk of obesity in California women. Journal of Nutrition, 133, 1070-1074.

[4]. Alaimo, K., and Froelich, A. (2004). Alternative construction of a food security and hunger measure from 1995 Current Population Survey Food Security Supplement data. Paper presented at the Workshop on the Measurement of Food Insecurity and Hunger, July 15, 2004. Panel to Review the U.S. Department of Agriculture's Measurement of Food Insecurity and Hunger. (http://www7.nationalacademies.org/cnstat/froelich_alaimo_paper.pdf).

[5]. Alaimo, K., Olson, C.M., and Frongillo, E.A. (1999). Importance of cognitive testing for survey items: An example from food security questionnaires. Journal of Nutrition Education, 31(5), 269-275.

[6]. Alaimo, K., Olson, C.M., and Frongillo, E.A. (2001a). Low family income and food insufficiency in relation to overweight in U.S. children-Is there a paradox? Archives of Pediatrics and Adolescent Medicine, 155, 1161-1167.

[7]. Alaimo, K., Olson, C.M., and Frongillo, E.A. (2001b). Food insufficiency and American school-aged children's cognitive, academic and psychosocial development. Pediatrics, 108, 44-53.

[8]. Alaimo, K., Olson, C., Frongillo, E., and Briefel, R. (2001c). Food insufficiency, poverty, and health in U.S. pre-school and schoolage children. American Journal of Public Health, 91, 781-786.

[9]. Alaimo, K., Olson, C.M., and Frongillo E.A. (2002). Family food insufficiency, but not low family income, is positively associated with dysthymia and suicide symptoms in adolescents. Journal of Nutrition, 132, 719-725.

[10]. Ali Mohammad, (1987 Monograph) Some Aspects of Food Security and Agricultural Development in West Asia, Centre of West Asian Studies, A.M.U. Aligarh pp 1-70.

[11]. Ziegler H. 2001 National Family Health Survey Programme 2001 and 2005

[12]. Planning Commission of India 2008

[13]. Andersen, E.B. (1980). Discrete statistical models with social science applications. Amsterdam: North-Holland

[14]. Planning Commission of India 2000.

[15]. Planning Commission of India 2011

[16]. FAO, Food Security Report 1986. 